\title{
Inter-Language Translation from Chinese to Indonesian: Strategies and Adjustments
}

\section{Clara Herlina Karjo}

English Department, Bina Nusantara University, Indonesia

Email: clara2666@binus.ac.id

\section{Yi Ying (Corresponding Author)}

Chinese Department, Bina Nusantara University, Indonesia

Email: yi_ying@binus.edu

\section{Fu Ruomei}

Chinese Department, Bina Nusantara University, Indonesia

Email: rosemary@binus.edu

\author{
Article History \\ Received: 30 March, 2021 \\ Revised: 26 April, 2021 \\ Accepted: 20 May, 2021 \\ Published: 23 May, 2021 \\ Copyright @ 2021 ARPG \& \\ Author \\ This work is licensed under \\ the Creative Commons \\ Attribution International \\ (क) (1) $\mathrm{CC}$ \\ BY: Creative Commons \\ Attribution License 4.0
}

\begin{abstract}
Translation usually involves two languages, the source language, and the target language. However, there is a certain situation that compels the use of an intermediary language for translating a source language (SL) text into a target language (TL) text. For example, when the source language texts (such as texts in Chinese) are not easily available in the target language country (such as Indonesia). This paper analyzed the strategies and adjustments made by the translators in doing inter-language translation or translation through an intermediary language, from Chinese to English to Indonesian. The purpose of this research is to compare two versions of translation, the first being the Indonesian translation from English as an intermediary language (IT) and the second is the Indonesian translation directly from Chinese (DT). Research revealed that IT used loss strategy while DT used gain strategy in the form of syntactic and semantic adjustments because there are many culture-specific items of the source language text that are unknown to either English or Indonesian. The findings imply that the translators should have enough skill and knowledge to enable them to accurately communicate the message of the source text to the target text audience.
\end{abstract}

Keywords: Cultural terms; Gain and loss; Inter-language translation; Intermediary language; Semantic adjustment.

\section{Introduction}

Classical Chinese text is known to be difficult to translate (Rosemont, 2015) because of the complexity of the interrelation between syntax and semantics in the Chinese language. For example, in the opening line of the Chinese classic, Dao De Jing, there is a sentence 道可道非常道 (Dao ke dao fei chang dao). This sentence can be described as follow:

- 道(in first, third, and sixth positions here) means "path", "way", "the way”, "to follow”, "to go down a path". It also means "to speak", "doctrines".

- 可 functions like English modal “can”.

- 非a sign of negation; usually in the sense of "not the same as".

- 常 “unvarying”, “constant”, “enduring”, “unchanging”.

Thus, literally, the whole sentence can be translated as:

\section{道可道非常道 \\ Dao ke dao fei chang dao}

Dao cannot dao not same unchanging dao

However, the same sentence can have several versions of translation in English, such as:

1. The way that can be told is not an Unvarying Way.

2. The way that can be spoken of is not the constant way.

3. A way that can be followed is not constant.

4. Way-making that can be put into words is not way-making.

Besides the syntactic-semantic relation, the Chinese language also contains a lot of culture-specific terms that make them difficult to transfer into another language (Nida, 2015). Culture-specific items, according to Chesterman (2012) are abstract or concrete concepts relating to a religious belief, social custom, or even a type of food. The source language word may express a concept that is unknown in the target language culture. For instance, the concept of 'dao' can be translated as 'way' in English or jalan in Indonesian, but the translations cannot convey precisely the meaning of 'dao'. Li (2016), claimed that the expressions closely associated with cultural contexts 
occurring in one language cannot be directly translated into another if there is no equivalent term in the target language.

The misreading of Chinese characters and mistranslation of Chinese culture are some issues that should be addressed in translating Chinese classics (Cui and $\mathrm{Xu}, 2016$ ). However, despite the difficulties, translating is considered as the act of communication which attempts to relay, across cultural and linguistic boundaries another act of communication (which may have been intended for different cultures) (Hatim and Mason, 2005). This statement indicates that everything that can be expressed in one language can be communicated in another language. Therefore, even though Chinese classics are difficult to translate, their message can still be transferred into other languages.

One way to disseminate the message of classical text such as Chinese classics to a wider audience of other languages is by performing an inter-language translation or indirect translation. The indirect translation is considered as "a translation based on a source (or sources) which is itself a translation into a language other than the language of the original, or the target language" (Kittel and Frank, 1991).

The practice of indirect translation or "the translation of translation" (Gambier, 2004) has a long-standing history (for example in the translation of Bible, I-Ching, etc.), and it has been widespread in today's society. Due to globalization, inter-language translation tends to be done from one peripheral language into another via a central language (Heilbron, 2010). For example, a text in the Kazakh language should be translated into English via Russian (Zhumabekova and Mirzoyeva, 2016). Russian is used as the intermediary language as it is a dominant language system within the countries which previously were under Russian government. Thus, intercultural text transfer in these countries is often mediated by dominant system (Assis Rosa et al., 2017).

On the contrary, inter-language translation that occurs in Indonesia, i.e. from Chinese into Indonesian, which should be done via English, is more likely due to the difficulty in obtaining the texts in original language. Most of the Chinese literary works that are translated into Indonesian were translated from their English versions. Hence, the unavailability of source language language texts (such as literary works) is one motivation for the need of indirect translation (Assis Rosa et al., 2017).

Indirect translation from Chinese into Indonesian, to the best of our knowledge, has not been thoroughly researched. Therefore, the present study attempts to fill the gap in research regarding indirect translation from Chinese into Indonesian via English. In this paper, we will compare two kinds of translation of one Chinese classics "Sun Zi, the Art of War". The first is a Direct Translation (DT) from Chinese version to Indonesian and the second is the Indirect Translation (IT) from the English version to Indonesian.

The objective of this study is to compare the translation results of IT and DT. To achieve this objective, two research questions will be addressed in this study:

1. What kind of translation strategies are applied in IT and DT of 'Sun Zi' from Chinese to Indonesian?

2. What kind of semantic and syntactic adjustments do the IT and DT translators make to achieve an understandable translation of Chinese classics into Indonesian?

\section{Literature Review}

A Direct Translation (DT) is made directly from the source language text into a target language text without a mediating language. On the other hand, indirect translation is "double, intermediate, mediated, mixed, pivot, relayed, or second-hand translation" (Assis Rosa et al., 2017). Indirect Translation (IT) which can also be called interlanguage translation or 'retranslation' appears mostly in publications dealing with Chinese as the ultimate SL or TL (Bauer, 1999). In this paper, I apply the term inter-language translation.

Through indirect translation, certain classic works of world literature have found their way into languages of limited diffusion (Landers, 2011). Indirect translation has always been a common phenomenon in literary translation that (Dollerup, 2000) pointed out that IT is "indeed so common that, in literary studies, for instance, it is hardly noted at all." Thus, Chinese classics such as Sun Zi, Confucius, I-Ching can inspire a lot of people around the world if they are translated from English rather than directly from Chinese. In the case of Chinese or Japanese as the ultimate SL, an inter-language translation is needed because of a lack of translators or of linguistic competence in the SL or due to the difficulty in obtaining the original text (Assis Rosa et al., 2017; Cui and Xu, 2016). Meanwhile, (Akkaliyeva et al., 2021) mentioned that inter-language translation makes possible the dissemination of minor literatures worldwide. Minor literatures here means literatures written in peripheral languages such as Kazakh language.

However, indirect translation also has some limitations. According to Landers (2011), the most important problem is the misinterpretation that occurred in the first translation (intermediate translation) will be reproduced in the second translation (the final translation). Landers (2011) calls it a Xerox effect: "a copy of a copy of a copy loses sharpness and detail with each successive passage through the process". Therefore, Li (2016) stated that IT has always been considered the choice of last resort even though it is common and natural. However, even though interlanguage translation has always been criticized as being unfaithful translation, Yu (2017) claimed that is is not always true as the main concern of the translation is to convey the purpose of the source text.

Misinterpretation or mistranslation often happens when there are a lot of cultural terms involved. Culture-laden words are known to be difficult to translate since they are related to the cultural knowledge and cultural background of the translators. In doing inter-language translation the last translator is obliged to have sufficient cultural knowledge of the Source Language (SL), the Intermediary Language (IL), and the Target Language (TL) to be able to produce an idiomatic translation in the TL. Particularly, in the present study, the SL is Chinese, the IL is English and the TL is Indonesian. 
Chesterman (2012), defined culture-specific items as the source-language word which may express a concept that is unknown in the target culture. The concept in question may be abstract or concrete; it may relate to a religious belief, a social custom, or even a type of food. Such concepts are often referred to as 'culture specific'.

Accordingly, translating texts from two or more distinct cultures will bring the consequence of gain and loss in the translation. Davies (2013), asserted that the extent of gain and loss in the translation of culture-specific items are determined by the distance and differences between cultures. Gain, according to Bassnett (2013) is the addition of clarification of the source language text during the process of translation. Similarly, Vinay and Darbelnet (2004) suggested that gain is possible when a new communication act was made to create a new thing out of a previously existing one. Relative expressional abilities and creativity enable someone to create something new. Moreover, gain enables the translator to produce a target text which is far better than the source text, making it clearer and more legible to the readers.

On the other hand, 'loss' is something from the source language context that is replaced in the target language context. Until now, there have been two different opinions regarding the loss in translation (Katan, 2014). One side claims that everything can be translated without loss, while the other side claims that nothing can be translated without loss. Most experts, however, tend to believe that loss often occurs in translation, especially if the gap between the SL culture and TL culture is relatively large. Li (2016) for example, stated that the expressions which are closely associated with cultural contexts in one language cannot be directly translated into another if there is no equivalent term in the target language. Thus, the loss can occur. Similarly, Dizdar (2014) affirmed that when a translator fails to render the entire culture-specific items and linguistic features of the target text, there is more probability of loss. Alwazna (2014), also claimed that loss can occur if the translator is not competent in the target language.

To avoid loss in translation especially for rendering cultural terms, translators have to resort to translation strategies that have been proposed by translation experts. Theorists such as Vinay and Darbelnet (1995) offered some strategies which they called oblique translation strategies which consist of:

- Transposition: changes from one part of speech in SL into another part of speech in TL. This change can be obligatory as in des son lever into she got up, or optional as in she got up into qu'elle s'est levee.

- Modulation: changes in semantic meaning and SL/TL point of view. Modulation can be obligatory as in the time when becomes le moment ou or optional as in is not difficult to show - il est facile de demontrer

- Equivalence: describing the same situation with different structure and stylistic devices. For example, to translate idioms or proverbs, it is the meaning that is transferred not the metaphors. As an example, a proverb comme un chien un jeu de quilles (like a dog play with its fur) is translated into like a bull in a china shop.

- Adaptation: change the cultural reference if the situation in the SL culture cannot be found in TL. For example, in English culture, there is a game of cricket but in French tour de France is widely known.

Moreover, Sun (2016) added another translation strategy that can be used for translating Chinese classics,

- Explaining: describing the SL term if a similar term cannot be found in TL or if the SL term has a complex meaning that cannot be conveyed in one or two words. For example, the word 'dao', cannot just be translated into jalan (way). It should be translated with a description in the SL.

\section{Methodology}

This study used a descriptive qualitative design. The material for this study is a Chinese classical text, entitled "The Art of War", written by Sun Zi in the $10^{\text {th }}$ century. The Chinese text will be referred to as SL text. The SL text was translated into English by an English native James Trapp, who has a degree in Chinese at SOAS, University of London. The English translation was referred to as ET (English Translation) which functions as an intermediary language. The English text was then translated into Indonesian by Clara Herlina, a native Indonesian who was educated in English Applied Linguistics. This translation was referred to as IT (Indirect Translation) because the translation was done from English, the intermediate language. For this study, the Chinese text was then translated directly into Indonesian. The Indonesian translation was done by Fu Ruomei, a native Chinese with a degree in Chinese education who is teaching in a private university in Indonesia, and Yi Ying, a native Indonesian with a degree in Chinese education. This translation was referred to DT (Direct Translation).

For the purpose of this study, we only used one chapter of the SL text (which originally consisted of nine chapters). All the sentences in this chapter were translated in three different versions (ET, IT, and DT). These three translation versions were then scutinized to discover the strategies used by each translator.

\section{Results}

The comparisons of translations are presented in tables consisting of four rows. The first column contains the Chinese Source Text (abbreviated as SL), the first Indonesian translation which is translated directly from Chinese is marked as Direct Translation (DT). The English translation which was also translated directly from Chinese is marked as English Translation (ET) and the second Indonesian translation which was translated from the English version is marked as Indirect Translation (IT). The translation results are discussed based on the strategies used and the kind of adjustment applied. 


\subsection{Deletion and Addition}

The first strategy found in the translation of The Art of War is deletion and addition. Deletion here means that some parts of the text are omitted in the translation, while addition means adding some elements in the TT. Usually, the omitted part is considered as understood or can be inferred from the context. On the contrary, the addition is used to emphasize or to clarify the meaning of some concepts.

Table-1. Deletion and Addition of Phrases

\begin{tabular}{l|l}
\hline SL & $\begin{array}{l}\text { 孫子曰: 兵者, 國之大事, 死生之地, 存亡之道, } \\
\text { 不可不察增。 } \\
\text { Sūn Zì yuē: Bīngzhě, guójiā dàshì, sǐshēng zhī dì, cúnwáng zhī dào, bùkě } \\
\text { bù chá yě. }\end{array}$ \\
\hline ET & $\begin{array}{l}\text { "War is the place where life and death meet." } \\
\text { Understanding the nature of war is of vital importance to the State. War is } \\
\text { the place where life and death meet: it is the road to destruction or } \\
\text { survival. It demands study. }\end{array}$ \\
\hline IT & $\begin{array}{l}\text { "Perang adalah tempat dimana hidup dan mati bertemu... » } \\
\text { Memahami sifat perang sangat penting bagi Negara. Perang adalah tempat } \\
\text { dimana hidup dan mati bertemu; ia adalah jalan menuju kehancuran atau } \\
\text { keselamatan. Ia perlu dipelajari. }\end{array}$ \\
\hline DT & $\begin{array}{l}\text { Sun Zi berkata, masalah perang adalah urusan penting yang menentukan } \\
\text { hidup dan matinya tentara dan rakyat, bahkan negara, sehingga mau tak } \\
\text { mau harus dipelajari secara saksama }\end{array}$ \\
\hline
\end{tabular}

Table one shows the first sample of a deletion in the translation. The SL includes the phrase 'Sūn Ž̌ yuē (Sunzi said) but in English translation, it is omitted. Consequently, in IT this phrase was not translated either. The phrase 'Sün Ž̌ yuē was considered unnecessary since the book was written by $\mathrm{Sun} \mathrm{Zi}$, so it can be inferred it was $\mathrm{Sun} \mathrm{Zi}$ who made the statement.

In DT, the translators added the phrase 'shibing hé rén' (tentara dan rakyat - soldier and people) to translate the phrase other hand, in DT, it was rendered as urusan penting yang menentukan hidup dan matinya tentara dan rakyat (an important matter that determines the life and death of the soldier and the people). There is a shift of focus here from 'place' to 'matter' in translating the word 'war'. The addition of a phrase is not useful because, in the context of war, those who were most likely involved were the soldiers and the people.

\subsection{Semantic Modulation}

Following Vinay and Darbelnet's theory, semantic modulation is the alternation of meaning in the SL and the TL. In this book, there are many terminologies or concepts which are not found in the target language, or conversely, there are various similar concepts in the target language (either English or Indonesian). Thus, the translators' task is to find the TL concept that can appropriately convey the meaning of SL concept.

Table-2. Alternation of Meaning in Terminology

\begin{tabular}{|c|c|}
\hline SL & $\begin{array}{l}\text { 故經之以五, 校之以計, 而索其情 : 一曰道, 二曰 } \\
\text { 天, 三曰地, 四曰將, 五曰法。 } \\
\text { Gù jīng zhī yǐ wǔ, jiào zhī yǐ jì, ér suǒ qí qíng: Yī yuē dào, èr yuē tiān, sān } \\
\text { yuē dì, sì yuē jiàng, wǔ yuē fă }\end{array}$ \\
\hline ET & $\begin{array}{l}\text { Five decisive factors: First is a Moral Compass; second is Heaven; third is } \\
\text { Earth; fourth is the Commander; fifth is Regulation. }\end{array}$ \\
\hline IT & $\begin{array}{l}\text { Lima faktor penentu: Pertama adalah Kompas Moral; kedua Langit; ketiga } \\
\text { Bumi; keempat Panglima; kelima Aturan }\end{array}$ \\
\hline DT & $\begin{array}{l}\text { Lima faktor yang harus diperhatikan: faktor pertama adalah moral, faktor } \\
\text { kedua adalah kondisi cuaca, faktor ketiga adalah keadaan geografi, faktor } \\
\text { keempat adalah jenderal,dan faktor kelima adalah hukum. }\end{array}$ \\
\hline
\end{tabular}

The difficulty in translating Chinese characters is if they are not put in sentential context. For example, the word '天tiān' in ET, it was translated into 'Heaven', although the word '天tiān' can mean 'day, sky, and heaven'. The literal meaning of 'heaven' in Indonesian is surga. However, this meaning is not correct since surga (heaven) is used to refer to a place for good people after death, often depicted as being above the sky. Since this sense is not suitable with the context, the IT rendered it into langit (sky). However, the DT translated the word '天tiān' into keadaan cuaca (weather condition), which is more appropriate in the context of war. Another difficulty is the word '地 $d i$ ' which is translated as 'Earth' and bumi in IT. Again, DT translated this term as keadaan geografi (geographical condition). The last one is the word '法 fă which means 'law', but in ET it was changed into 'regulation', thus in IT, it became aturan not as hukum in DT. All these samples show that ET did some semantic modulations of the SL. In 
effect, IT follows the translation of ET and the meaning of SL words changed a little bit although they are still understandable and connected with the context of war.

\subsection{Syntactic Transposition}

Another strategy proposed by Vinay and Darbelnet is a syntactic transposition by changing the grammatical unit from word to phrase or vice versa. In this strategy, the word order of the sentence can also be changed to achieve the appropriate translation of the SL.

Table-3. Syntactic Transposition

\begin{tabular}{l|l}
\hline SL & $\begin{array}{l}\text { 地者, 高下、遠近、險易、廣狹 } \\
\text { Dì zhě, gāo xià, yuănjìn, xiăn yì, guăng xiá }\end{array}$ \\
\hline ET & $\begin{array}{l}\text { Earth encompasses nearness and distance, ease and hindrance, wide plains } \\
\text { and narrow gorges }\end{array}$ \\
\hline IT & $\begin{array}{l}\text { Bumi menguasai kedekatan dan jarak, kemudahan dan hambatan, dataran } \\
\text { luas dan jurang sempit }\end{array}$ \\
\hline DT & $\begin{array}{l}\text { Keadaan geografi yang dimaksud adalah jauh atau dekatnya perjalanan, } \\
\text { tingkat keamanan topografi, luas atau sempitnya medan perang } \\
\text { 路程遠還是近, 地勢險要還是平坦, 戰場 開閭還 } \\
\text { 是狭察 } \\
\text { Lùchéng yuăn háishi jìn, dìshì xiănyào háishi píngtăn, zhànchăng kāikuò háishi } \\
\text { xiázhăi }\end{array}$ \\
\hline
\end{tabular}

Table three shows the application of grammatical transposition in which the SL uses noun phrase or adjective phrase such as 广狭 guăng xiá, while the ET and IT use binomial phrases in the translation. For example 遠yuănjìn - is translated into 'nearness and distance' (ET) and kedekatan dan jarak (IT). However, DT changed this phrase into a noun phrase jauh dekatnya perjalanan (the nearness and distance of journey - Lùchéng yuăn háishi jìn 路程遠還是近). In this translation, DT added the word perjalanan (journey) to clarify the meaning.

The second phrase, 險易- xiăn yì - was translated as 'ease and hindrance' in ET and kemudahan dan hambatan in IT. However, DT modified this phrase into tingkat keamanan topografi (the safety level of the topography - Dishi xiǎnyào háishi píngtăn 地勢險要還是平坦

The last phrase is 廣狹 guăng xiá, which literally means 'wide and narrow'. But in ET, it was added into 'wide plains and narrow gorges', which was automatically translated into dataran luas dan jurang sempit in IT, which was a literal translation of ET. However, in DT, it was translated into luas dan sempitnya medan perang (the width and narrowness of battlefield - 'Zhànchăng kāikuò háisi xiázhăi 戰場開闊還是狹宗.The translation of SL phrase 廣㹨 guăng xiá has undergone two modifications. In ET and IT, the translators changed the original adjective phrase into noun phrases by adding additional nouns (plains and gorges), while the DT translators added the word 'battlefield' in the noun phrase.

\subsection{Adaptation and Explanation}

Sometimes ST concepts cannot be translated into the target language because there are no equivalent terms in the target language. In this case, the translator can try to explain the terms in the target language as can be seen in the following translation.

Table-4. Explaining Untranslatable Term

\begin{tabular}{l|l}
\hline SL & $\begin{array}{l}\text { 死 生 地 } \\
\text { Sǐ shēng dì }\end{array}$ \\
\hline ET & Matters of life and death \\
\hline IT & Urusan hidup dan mati \\
\hline DT & $\begin{array}{l}\text { Si Di (daerah di mana tidak ada jalan keluar selain bertempur mati-matian) } \\
\text { atau Sheng } D i \text { (kebalikan dari Si Di) }\end{array}$ \\
\hline
\end{tabular}

The phrase 死生 地_Š̌ shēng dì was translated into a binomial phrase 'matters of life and death' in ET and urusan hidup dan mati in IT. There is a change of meaning for the word 地 - dì, which literally means 'ground, earth or place' but in this case, it was translated into 'matters'. Moreover, there is no explanation why it is a matter of life and death. The DT translators, however, cannot find the appropriate terminology in Indonesian, so they used the adaptation technique by keeping the original terms and giving the explanation of those terms. Thus, the translation became "Si Di (daerah di mana tidak ada jalan keluar selain bertempur mati-matian) atau Sheng Di (kebalikan dari Si Di)". (Si Di - area in which there is no escape except fighting to death or Sheng Di (the opposite of Si Di). This difficulty in translating simple words such as Si Sheng Di shows that Chinese words have complex syntactic and semantic meanings that cannot be easily transferred to another language. 
The last strategy found in the translation of The Art of War is a semantic and syntactic transposition. The syntactic transposition involves the changing of grammatical units from words to phrases, for example from noun to noun phrases. Consequently, the meaning of the SL words is also expanded by the addition of extra words.

Table-5. Semantic and Syntactic Transposition

\begin{tabular}{|c|c|}
\hline SL & $\begin{array}{l}\text { 將者, 智、信、仁、勇、讝椋。 } \\
\text { Jiàng zhě, zhì, xìn, rén, yǒng, yán yě. }\end{array}$ \\
\hline $\mathrm{ET}$ & $\begin{array}{l}\text { The General must be possessed of wisdom, honesty, benevolence, courage and } \\
\text { discipline }\end{array}$ \\
\hline IT & $\begin{array}{l}\text { Jenderal harus memiliki kebijaksanaan, kejujuran, kebajikan, keberanian dan } \\
\text { disiplin }\end{array}$ \\
\hline DT & $\begin{array}{l}\text { Jenderal yang dimaksud adalah apakah jenderal memiliki lima kelebihan,yaitu: } \\
\text { kecerdasan dalam memimpin, kejujuran memberikan hukuman dan imbalan, } \\
\text { mengetahui cara mengasihi orang lain dengan benar, memiliki keberanian dan } \\
\text { ketegasan, ketat dan berdisiplin secara militer } \\
\text { 將領必須足智多謀, 獎罰分明, 誠實有信, 關愛部 } \\
\text { 下, 待人仁義, 勇敢果斷, 軍紀嚴明。 } \\
\text { Jiànglǐng bìxū zúzhìduōmóu, jiăng fá fēnmíng, chéngshí yǒu xìn, guān'ài } \\
\text { bùxià, dàirén rényì, yǒnggăn guǒduàn, jūnjì yánmíng. }\end{array}$ \\
\hline
\end{tabular}

Five terms underwent syntactic and semantic transposition. There were no changes in syntactic form from SL to ET and IT. The SL as well as the translations used word form (noun). The changes occurred in the DT translation, the original nouns were changed into noun phrases or verb phrases. The first word, 智 - zhì was translated into 'wisdom' (ET) and kebijaksanaan (IT). This word was rendered into a noun phrase kecerdasan dalam memimpin (intelligence in leading - 獎罰分明 - jiăng fá fēnmíng) in DT. The second word, 信- xìn was translated into 'honesty' or kejujuran in ET and IT. However, DT expanded the word into a noun phrase kejujuran dalam memberikan hukuman dan imbalan (honesty in giving reward and punishment- 誠實有信 - chéngshí yǒu xìn). The third word, 仁- rén was translated into 'benevolence' or kebajikan. DT translated this word into a verb phrase mengetahui cara mengasihi orang lain dengan benar (knowing how to treat people correctly - 待人仁義 - dàirén rényì). The fourth word, 勇 - yǒng was rendered into 'courage' or keberanian and it was changed into a verb phrase memiliki keberanian dan ketegasan (having courage and austerity - 勇敢果䠪 - yǒnggăn guǒduàn). The final word in this category is 嚴也 - yán yě which means 'discipline' in English and a borrowing word disiplin in Indonesian. However, the DT added the sense to become berdisiplin secara militer (having military discipline 軍紀嚴明 - jūnjì yánmíng).

\section{Discussion}

Indirect translation or intermediary translation occurs for certain reasons. In countries whose languages are considered peripheral language, a translation through a more dominant language system is necessary to be done. This can be exemplified by Kazakh's literary works which should be translated into Russian before being translated into English or vice versa (Zhumabekova and Mirzoyeva, 2016). This method of translation is common in common in bilingual countries such as Kazakhstan where all the people are bilinguals and Russian is considered as their second native language.

However, the need for indirect translation in Indonesia arises for a different reason. Literary works in uncommon foreign languages (such as Chinese, Japanese, Thai, etc.) are not available here. East Asian literatures are usually translated from the English versions. Thus, the main motivation for doing the inter-language translation in Indonesia is the difficulty in obtaining the text in its original language (Rosa et al., 2017). Another factor is the fewer number of Chinese-Indonesian translators compared to those of English-Indonesian.

Indirect translation follows along the following designation: the ultimate ST/SL > mediating text/language > ultimate TT/TL (Rosa et al., 2017). In other words, inter-language translation commonly involves three different languages, notwithstanding the relations among these languages are. The mediating language might be related (as the second language) of the source language, or it can be a totally different language, such as Chinese and English.

The analysis of the direct translation (DT) from Chinese into Indonesian in this study shows that the translator mostly apply explanatory translation by giving extra information to the meaning of a specific concept. For example, the word "zhi" was translated into "kejujuran dalam memberi hukuman dan imbalan" (honesty in giving penalty and reward). The translator here felt that the context was necessary to clarify or convey the original meaning.

On the contrary, in inter-language translation, the translator followed the style of the mediating text. For instance, the word "zhi" was only translated as "honesty" in English, which later literally translated as "kejujuran" in Indonesian. Other example is the phrase "nearness and distance" which was literally translated into "kedekatan dan jarak", meanwhile the DT translator rendered it into "dekat dan jauhnya perjalanan" (the nearness and the distance of the journey). 
As we can see in the above examples, Inter-language translation brings about the problem of language orientation. Since the IT translator was not proficient in SL (Chinese), she relied her translation mostly from the English version. This is why, in terms of the closeness to the ST, IT tends to be negatively evaluated. Assis Rosa et al. (2017), claimed that IT increased the distance to the ultimate ST.

As a result, IT translator often used 'loss' strategy, such as deletion, omission, alteration, and literal translation. Tiwiyanti and Retnomurti (2017), stated that the loss is made to make the TT acceptable and easy to read and understand. They also asserted that loss occurs because there is a cultural gap lies between the two respected languages. Hence, in this paper, we argue that the IT translator used the loss strategy because the intermediary language translator also used similar strategy. However, we concurred with Yu (2017) that the purpose of translation is to transmit the message of the original text. Accordingly, loss strategy should not become a problem as long as the ultimate readers understand the basic message of the texts.

In contrast, DT translator attempted to use more 'gain' strategy, since she wanted the readers to understand fully the message of the SL text. Gain strategy was applied by giving explanation, paraphrasing cultural concepts, and semantic modulation. Gain strategy enables us to assume that the translator can produce a target text which is far better from the source text by making it clearer and more legible to the reader (Tiwiyanti and Retnomurti, 2017). Vinay and Darbelnet described gain strategy as a way to express the unexpressed situational element.

After all, we also agree with Sharma and Noval (2020) that every act of translation is a gain, as long as the message of the ST is transmitted to the TT, either directly or via intermediary language.

\section{Conclusion}

Translating Chinese classics, especially The Art of War by Sun $\mathrm{Zi}$ is extremely difficult because of the complicated interplay between syntax and semantic in the Chinese language. Moreover, certain culture-specific concepts cannot be transferred into the target language culture.

For this study, we have proposed two research questions. The first one related to the translation strategies used by the DT and IT translators in translating the Chinese classics. The second research question dealt with the syntactic and semantic adjustments used in producing the translation. We discovered that both DT and IT translators used four types of translation strategy, which were Deletion and Addition, Semantic Modulation, Syntactic Transposition, and Adaptation and Explanation. Meanwhile, different kinds of semantic and syntactic adjustments were also reflected in the translation strategies used by both translators.

These translation strategies can result in gain and loss in the translation. Thus, deletion and semantic modulation may cause loss in the translation, while the explanation and addition strategies can cause gain in the translation.

Regarding the types of translation, we found that DT (direct translation) from Chinese to Indonesian tends to use gain strategy, in which the translators often use explanation, paraphrasing, addition and syntactic and semantic transposition. On the other hand, the English Translation (ET), and IT (Indirect Translation) tend to use loss strategy because there were some omissions and out of context translation, thus some of the SL meanings were not fully transferred. Overall, both kinds of translation (IT and DT) are acceptable as long as they can be understood correctly by the TL audience.

However, the findings of this study suggest that the results of Indirect Translation are more similar to the intermediary translation (English). Meanwhile, the Direct Translation results are more comparable to the Source Language texts. Thus, although the message of the original text can be conveyed in the target language, certain subtle meanings are lost during the process of translation using intermediary language.

This study, nevertheless, did not discuss the comprehensibility and acceptability of the translation by the TL audience. Therefore, in future research, the writers would like to involve TL readers to give their judgment on the acceptability and comprehensibility of direct and indirect translations.

\section{References}

Akkaliyeva, A., Abdykhanova, B., Meirambekova, L., Jambaeyva, Z. and Tussupbekova, G. (2021). Translation as a communication strategy in representing national culture. Social Inclusion, 9(1): 5-13. Available: https://doi.org/10.17645/SI.V9I1.3455

Alwazna, R. Y. (2014). The cultural aspect of translation: The workability of cultural translation strategies in translating culture-specific texts. In Life Science Journal, 11(11): Available: http://www.lifesciencesite.com

Assis Rosa, A., Pięta, H. and Bueno Maia, R. (2017). Translation studies theoretical, methodological and terminological issues regarding indirect translation: An overview. Translation Studies, 10(2): 113-32. Available: https://doi.org/10.1080/14781700.2017.1285247

Bassnett, S. (2013). Translation studies. Routledge. https://doi.org/10.1017/CBO9781107415324.004

Bauer, W. (1999). The role of intermediate languages in translations from Chinese into German. De l'un au multiple. V. Alleton and M. Lackner (Eds.): Editions de la Maisons de Sciences de l'Homme.

Chesterman, A. (2012). Translating culture-specific items. In M. Baker (ED.). In Other Words: Routledge.

Cui, Y. and Xu, J. (2016). Translation of Chinese classics: Theory and practice. Babel, 62(2): 332-39.

Davies, A. (2013). Native speakers and native users: Loss and gain. Cambridge University Press. https://books.google.com/books?hl=en\&lr=\&id=DTooAAAAQBAJ\&oi=fnd\&pg=PR7\&dq=Alan+Davies+1 oss+and+gain\&ots=bBpFILP5-Q\&sig=eQ5fSFCLLu2wR9tLezPv1t9E bA 
Dizdar, D. (2014). Instrumental thinking in translation studies. Target: International Journal of Translation Studies, 26(2): 206-23.

Dollerup, C. (2000). Relay and support translations. In Alan Chesterman, S. Salvador,and Y. Gambier (Eds.).

Translation in Context .John Benjamins: 17-26. Available: www.cay-dollerup.dk

Gambier, Y. (2004). La retraduction, retour et détour. Meta:Translator's Journal: Available: https://www.academia.edu/download/31205307/002799ar.pdf

Hatim, B. and Mason, I. (2005). The translator as communicator. Routledge.

Heilbron, J. (2010). Structure and dynamics of the world system of translation. Unesco, Symposium 'Translation and Cultural Mediation.

Katan, D. (2014). Translating cultures: An introduction for translators, interpreters and mediators. Routledge.

Kittel, H. and Frank, A. P. (1991). Introduction. Interculturality and the historical study of literary translation. H. Kittel and A. P. Frank (Eds.): Schmidt Verlag.

Landers, C. E. (2011). Literary translation: A practical guide. Multilingual Matters.

Li, M. (2016). Translation of culture-loaded terms in Chinese Classics. Language Research, 52(1): 50-62.

Nida, E. (2015). Context in translating. John Benjamins Publishing Company: Amsterdam.

Rosa, A. A., Pięta, H. and Bueno Maia, R. (2017). Theoretical, methodological and terminological issues regarding indirect translation: An overview. Translation Studies, 10(2): 113-32. Available: https://doi.org/10.1080/14781700.2017.1285247

Rosemont, H. (2015). Translating and interpreting Chinese philosophy. In the standford encyclopaedia of philosophy. Available: https://plato.stanford.edu/entries/chinese-translate-interpret/?utm_sq=g66kbgqztn

Sharma, A. and Noval, S. (2020). Translation: Adaptive articulation of culture and ELT. Journal of Critical Reviews, 7(8): 3359-66.

Sun, J. (2016). Cultural soft power in the translation of chinese classics. Cross-Cultural Communication, 12(6): 3337.

Tiwiyanti, L. and Retnomurti, A. (2017). Loss and gain in translation of culture-specific items in ahmad tohari's lintang Kemukus: A semantic study. Lingua Cultura, 11(1): 1-6. Available: https://doi.org/10.21512/lc.v11i1.1820

Vinay and Darbelnet, J. (1995). Comparative stylistics of French and English: A methodology for translation. John Benjamins.

Vinay and Darbelnet, J. (2004). A methodology for translation. The translation studies readers. L. Venuti (ed.: Routledge. 128-37.

Yu, Z. (2017). Relay translation of feminism in China: An intralingual case. Journal of Translation Studies, 1(2): Available: https://www.researchgate.net/publication/321758308

Zhumabekova, A. K. and Mirzoyeva, L. Y. (2016). Peculiarities of indirect translation from English into Kazakh via Russian language. Turkish Online Journal of Educational Technology: 189-94. Available: https://www.researchgate.net/publication/312127199_Peculiarities_of_indirect_translation_from_English_i nto_Kazakh_via_Russian_language 